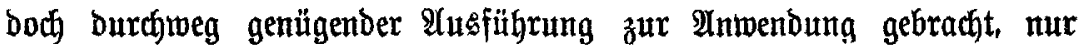

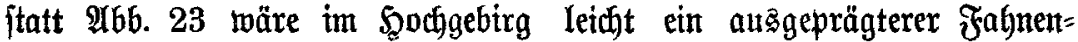

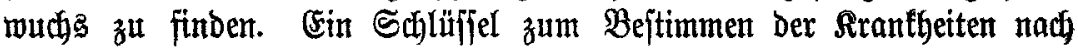

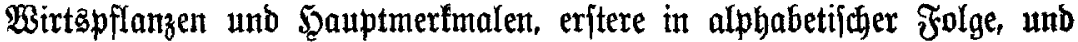

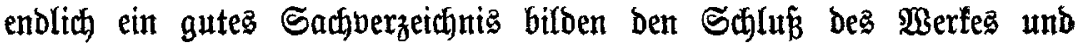
machen es auth zum \$ranobuch geetgnet. Fabriciū.

\title{
IV. Antizen.
}

\section{Prüfung für den Revierverwaltungsdienft.}

Infang September 1920 foll eine Bruffung für ben Rebterberwaltungebtenft ber Bribaten uff. abgebalten werben. Bur Brüfung werben folde צntwärter zugelaffen,

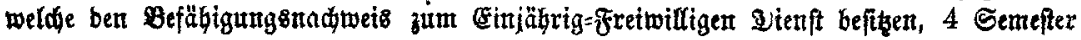
mit Exfolg an einer beutiden forftiden \$sodjoule fitubiext baben unb eine minbefiens

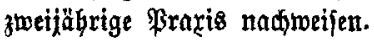

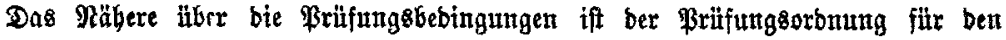
Mevierverwaltung bient ber Frivaten $\mathfrak{n} f \mathfrak{f}$. zn entnefment.

Anmelbungen finb tanter Beifügung ber in $\$ 4$ ber Prilfungsorbnung bezetdinteten

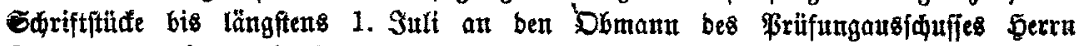

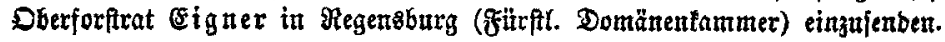

Der Borfizenbe bes bextiden Forftberein:

Dr. $\mathfrak{2}$ appes, Regierungsbireftor.

\section{Aus Badent.}

Dite Forf: unb Domänenbireftion ift aufgeb̧oben unb bie Berwaltung ber Dontünen unb Forftęn (Sefääftzabteifungen be Finanzminifteriums ïbertragen worben. Der feit=

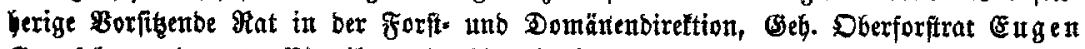
Fretf Yat im Finanjminifterium exnannt. Gleidzeitig wurbe ifm bie \&eitung ber Forfta abteilung in biejem Mintifterium

\section{Codestahrint.}

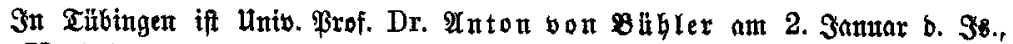
feinem 72. Geburtstage, geftorben. Bon 1896 bis Oftober 1919 bat ex in Tilbingen als Brofefior ber Forftwiffenfolaft gewirft. 